Bangladesh J. Plant Taxon. 28(2): 367-378, 2021 (December)

(C) 2021 Bangladesh Association of Plant Taxonomists

DOI: https://doi.org/10.3329/bjpt.v28i2.57132

\title{
STUDY OF MARINE SAND-DWELLING DINOFLAGELLATE WITH FOUR NEW RECORDS FROM THE CENTRAL SOUTH COAST OF VIET NAM
}

\author{
The Ho VAN ${ }^{*}$ ANd H'Yon NiÊ BING ${ }^{1}$ \\ Institute of Oceanography, Vietnam Academy of Science and Technology (VAST), \\ 01, Cau Da, Nha Trang, Khanh Hoa, Viet Nam
}

Keywords: Marine sand-dwelling; Dinoflagellates taxonomy; Vietnamese coast.

\begin{abstract}
In this study, marine sand samples were collected from the shallow intertidal zone of Nha Trang bay, Viet Nam. Taxonomic observations were conducted for the sanddwelling dinoflagellates using light, epifluorescent and scanning electron microscopy. Morphology characterizations of the four species namely, Amphidiniopsis hexagona, Thecadinium pseudokofoidii, Amphidinium herdmanii and Fukuyoa ruetzleri have been reported as new records for Vietnamese coastal waters. The genus Amphidiniopsis and Thecadinium are a new addition to the dinoflagellates flora of Viet Nam. Taxomomic descriptions and photographs of these species have been provided.
\end{abstract}

\section{Introduction}

Benthic dinoflagellates (including epiphytic and sand-dwelling species) consist of known potentially toxic species which produce toxins that cause ciguatera fish poisoning (CFP), a common illness associated with fish consumption in tropical areas. Benthic dinoflagellates have been found to be associated with sandy bottoms, dead corals, seagrasses, macroalgae, detrital aggregates and even artificial substrate in tropical and subtropical waters (Faust, 1995; Tester et al., 2014). Over the past decade in Viet Nam, surveys of the benthic dinoflagellates have mostly focused on epiphytic toxic species (Nguyen and Larsen, 2004; Ho et al., 2010; Ho and Nguyen, 2014; Ho and H'Yon, 2019), whereas sand-dwelling dinoflagellates have been poorly studied and information on them is insufficient. The aim of this study is to document the ocurrence of marine sand-dwelling dinoflagellates from the intertidal zone of Nha Trang Bay contribute to a basis for better understanding of the their global distribution. Toward said goal, four marine sand-dwelling dinoflagellate species viz., Amphidiniopsis hexagona, Thecadinium pseudokofoidii, Fukuyoa ruetzleri and Amphidinium herdmanii have been described in detail and illustrated herein.

\section{Materials and methods}

Samples were taken monthly (July - November 2013) from the shallow intertidal zone of Nha Trang bay $\left(109^{\circ} 13.218^{\prime} \mathrm{E}, 12^{\circ} 12.75^{\prime} \mathrm{N}\right)$ (Fig. 1). Surface sand samples were collected by snorkeling divers using plastic bags at a depth of 1-1.5 $\mathrm{m}$ and from the upper layer of sandy flat using a spoon during low tide. Water temperature $\left({ }^{\circ} \mathrm{C}\right)$ and salinity (psu) were measured every month during sampling collection in the water column.

In the laboratory, the sand samples were mixed and lightly shaken with filtered seawater taken from the same site and the material was passed through consecutive smaller sieve sizes (125 $\mu \mathrm{m}$,

${ }^{1}$ Tay Nguyen Institute for Scientific Research, Vietnam Academy of Science and Technology (VAST). 116 Xo Viet Nghe Tinh, Da Lat, Lam Dong, Viet Nam

*Corresponding author, E-mail: hovantheio@gmail.com 
$64 \mu \mathrm{m}, 32 \mu \mathrm{m}$ and $20 \mu \mathrm{m})$ to remove large particles. Material on the $64 \mu \mathrm{m}, 32 \mu \mathrm{m}$ and $20 \mu \mathrm{m}$ sieves were examined and observed using a Leica MZ 12 stereo microscope. Cells of dinoflagellates were sought and isolated by pipette. The wild cells were observed alive or preserved with lugol-iodine solution using light microscopy (LM). Cell demensions were measured by light microscopy using a calibrated ocular micrometer. Thecal plate patterns were observed after staining with calcofluor white M2R with a Leica LDMB microscope using equipped phase and differential interference contrasts, epifluorescence microscopy. Photographs were recorded with a digital camera (Olympus DP-71). For scanning electron microscopy (SEM), fixed specimens were isolated and placed on $5 \mu \mathrm{m}$ carbon membrane in a filter-holder (Millipore), rinsed three times with distilled water and dehydrated through an ethanol series of $15 \%, 30 \%$, $50 \%, 70 \%, 90 \%$ and $99.99 \%$, then air dried. The filter was mounted on an aluminium stub with carbon tape and coated with gold in a vacuum sputter coater. Specimens were observed using a JEOL JSM-5410 LV scanning electron microscope.

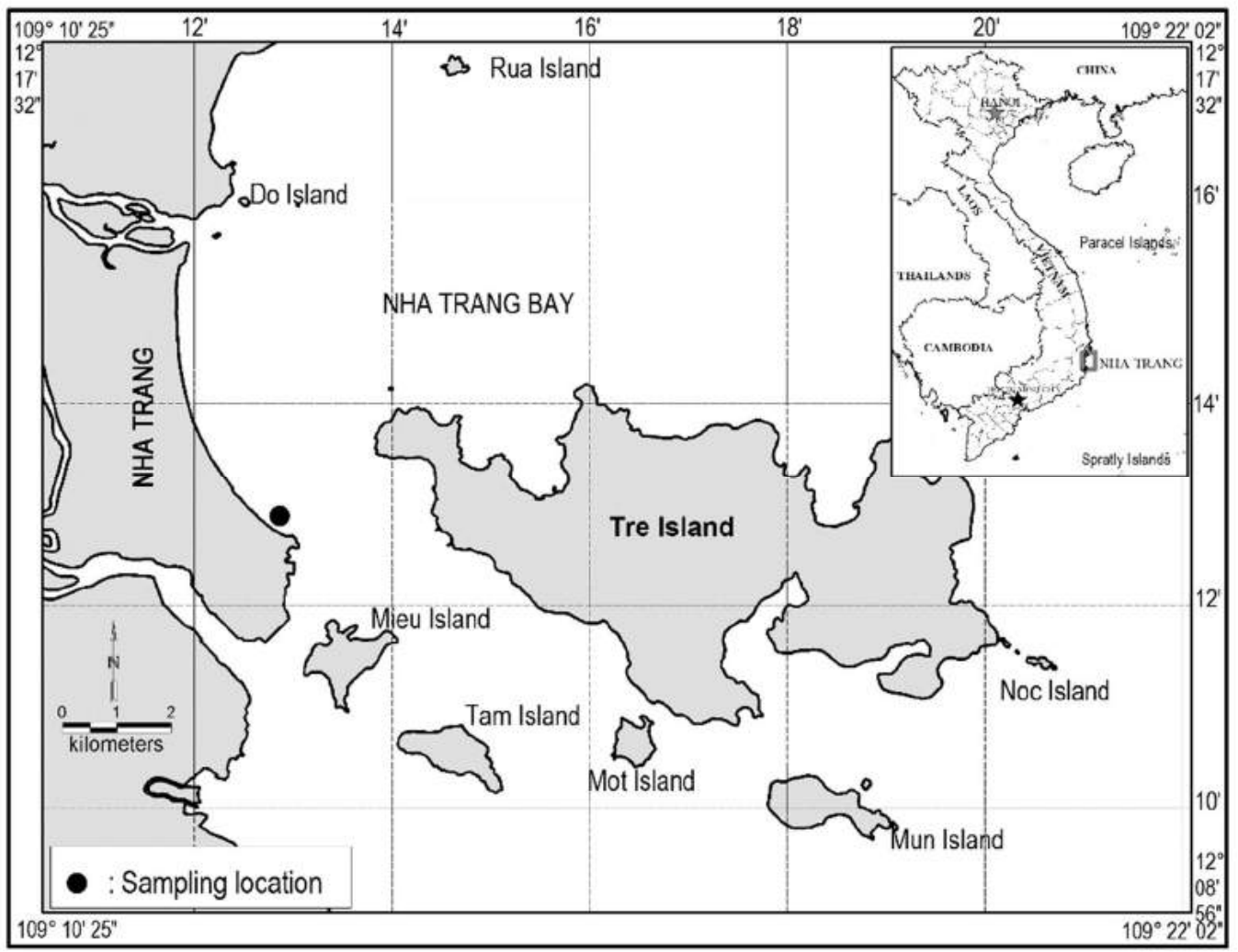

Fig. 1. Map showing the sampling location in Nha Trang bay, Viet Nam.

\section{Results and Discussion}

Based on an examination of cell size shape, cell surface morphology and architecture of thecal plates by light and scanning electron microscopy, the marine sand-dwelling dinoflagellates namely, Amphidiniopsis hexagona, Thecadinium pseudokofoidii, Amphidinium herdmanii and Fukuyoa ruetzleri have been described and documented with illustrations. 
Class: Dinophyceae West \& Fritch 1927; Order: Peridiniales Haeckel 1894; Family: Thecadiniaceae Balech 1956; Genus: Amphidiniopsis Woloszyńska 1929

Amphidiniopsis hexagona Yoshimatsu, Toriumi et Dodge

(Figs 2-7) (Yoshimatsu et al., 2000a: figs 10-17, figs 18a-d.)

Taxonomic remarks: Cells of $A$. hexagona are hexagonal in ventral view, slightly dorsoventrally flattened (Figs $2-4,7$ ). Thecal surface is slightly thick and coated with nipple-like processes (Figs 3-4). Cell dimensions range from 34.5-37 $\mu \mathrm{m}$ long and 30.8-31.7 $\mu \mathrm{m}$ wide. Measurements of our specimens were smaller than those reported in the document for A. hexagona (44-59 $\mu \mathrm{m}$ long and 40-53 $\mu \mathrm{m}$ wide, Yoshimatsu et al., 2000a). The plate formula is Po, 4', 2a,

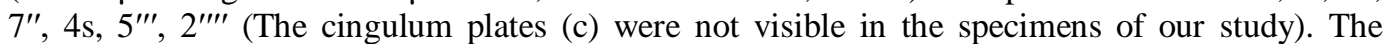
epitheca is short, $6.5-7.5 \mu \mathrm{m}$ long. The epitheca consists of thirteen plates: an apical pore plate (Po), four apical $\left(1^{\prime}, 2^{\prime}, 3^{\prime}\right.$ and $\left.4^{\prime}\right)$, two anterior intercalary (1a, 2a), and seven precingular plates (1", 2", 3", 4", 5", 6" and 7") (Figs 5-6). Four apical plates are of equal size. The anterior intercalary plate 1a is pentagonal and the plate $2 \mathrm{a}$ is long and narrow. Plate $1 "$ is five-sided, plates $2^{\prime \prime}, 3^{\prime \prime}, 4^{\prime \prime}, 5^{\prime \prime}, 6^{\prime \prime}$ are four-sided and plate 7" is trapezoidal. The cingulum is deep and equatorial. It
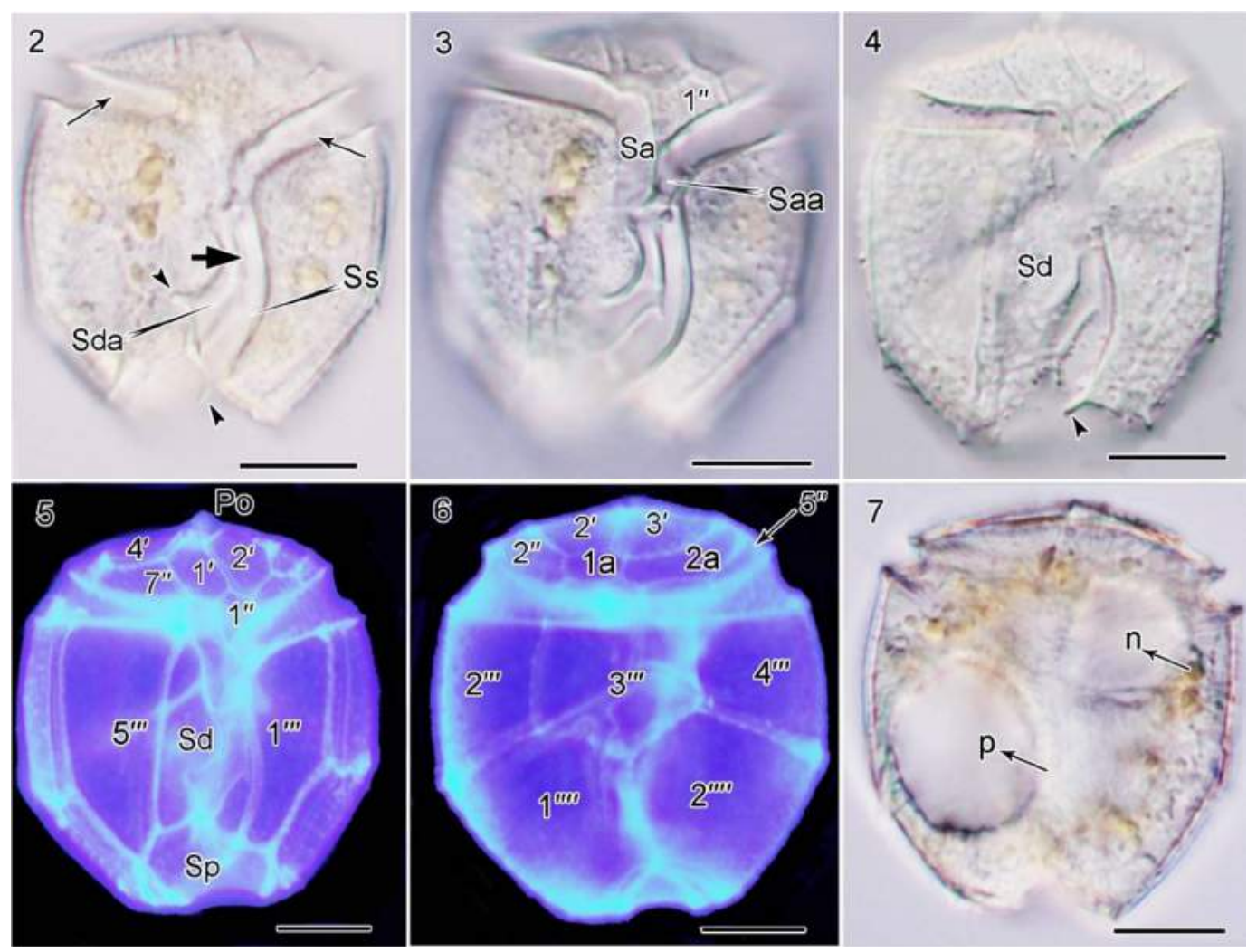

Figs 2-7. Micrographs of Amphidiniopsis hexagona under light and epifluorescent microscopy. Fig. 2.

Ventral view showing a small epitheca and large hypotheca, cingulum (long arrows) and sulcus (arrow) and two spines emerged at end of the plates Sda and Ss (arrowheads). Figs 3-5. Ventral view. Fig. 6. Dorsal view showing the epithecal and hypothecal plates. Fig. 7. Dorsal view showing a pusule (marked p) and nucleus (marked n) dorsally situated in hypotheca (arrow). Scale bars: $10 \mu \mathrm{m}$. 
is sinistral torsion and displaced by a deeply as it is wide. The sulcus includes six plates: anterior, right, left and posterior plates (Sa, Sd, Ss and Sp) (Figs 3-5), as well as to two anterior and right accessory sulcus plates (Saa and Sda) (Figs 2-3). Two spines are present at the end of plates Sda and Ss (Figs 2, 4).

Hypotheca is about $28-30 \mu \mathrm{m}$ long and notched at the antapex (Figs 5-7). The hypotheca contains seven plates: five postcingular plates (1'"', $2^{\prime \prime \prime}, 3^{\prime \prime \prime}, 4^{\prime \prime \prime}$ and $\left.5^{\prime \prime \prime}\right)$, and two antapical plates $\left(1^{\prime \prime \prime \prime}, 2^{\prime \prime \prime \prime}\right)$. The first and fifth postcingular plates are wide and their surface covers most of the ventral side of the cell (Figs 5-6). The second and fourth plates are medium in sized and positioned dorsally. The third plate, the largest in the series of postcingular plates, is five-sided and situated at the posterior part of hypotheca. The first and second antapical plates are equally large and arranged symmetrically (Fig. 6).

At present, twenty-four Amphidiniopsis species have been identified and described (Yoshimatsu et al., 2000a; Murray and Patterson, 2002a; Toriumi et al., 2002; Hoppenrath, 2000a; Hoppenrath et al., 2009, 2012, 2014; Reñé et al., 2000; Selina and Morozova, 2017; Selina, 2016; Selina and Hoppenrath, 2013). Among them, A. aculeata, A. konovalovae, A. strita, A. swedmakii, A. hirsuta and A. hexagona are similiar in shape, size and arrangement of epithecal and hypothecal plates. A. hexagona is distinguished from the five former by the shape and size of $3^{\prime \prime \prime}, 5^{\prime \prime \prime}, 2^{\prime \prime \prime \prime}$ plates, the number and shape of anterior intercalary plates (a), the presence or absence of two spines at the end of plates Sda and Ss and the presence or absence of spines at antapical margin.

Distribution: A. hexagona was found on sandy beach, Shirarahama, Wakayama Prefecture in Japan (Yoshimatsu et al., 2000a). Lately, it has been reported from sandy sediment samples in Botany Bay, Sydney, Australia (Murray, 2003). This is the first record of A. hexagona in Viet Nam and genus Amphidiniopsis is a new addition to the dinoflagellate flora of Viet Nam. This species could be frequently observed and never in high abundance.

\section{Class: Dinophyceae West \& Fritch 1927; Order: Peridiniales Haeckel 1894; Family: Thecadiniaceae Balech 1956; Genus: Thecadinium Kofoid \& Skogsberg 1928}

Thecadinium pseudokofoidii Selina, Efimova \& Hoppenrath

(Figs 8-13) (Selina et al., 2019: figs 8-12, 32-57)

Taxonomic remarks: Cells of $T$. pseudokofoidii have golden-brown chloroplasts (Figs 8-9). Cells are flattened laterally, broadly oval, slightly posteriorly point antapex, as illustrated in lateral view. Cells range in size from $25-32 \mu \mathrm{m}$ long and $24.5-35 \mu \mathrm{m}$ deep. The nucleus is dorsally located in the lower of the hypotheca (Fig. 9). The plate formula is Po, Pt, 4', 1a, 3", 5c, 8s, 4"', $1^{\prime \prime \prime}$ (Selina et al., 2019). The epitheca is very short. All epithecal plates are ornamented with rough ribs and large pores (Fig. 12). The epithecal plates were not visible in our specimens of present study. The hypotheca consists of four postcingular and one antapical plates (1"', $2^{\prime \prime \prime}, 3^{\prime \prime \prime}, 4^{\prime \prime \prime}$ and $\left.1^{\prime \prime \prime \prime}\right)$. The second and fourth postcingular plates are the largest and cover most of the right and left sides of the hypotheca. Their thecal surface is smooth and perforated by numerous small pores, these pores are found mainly at the margins of the lateral plates ( $2^{\prime \prime \prime}$ and $\left.44^{\prime \prime \prime}\right)$ and are lacking at plate centers (Figs 11-13). The narrow cingulum is deep and does not displace.

The genus Thecadinium currently includes nine species described (Yoshimatsu et al., 2000b; Hoppenrath, 2000a,b; Hoppenrath et al., 2014; Selina et al., 2019). Of the nine species, only two T. pseudokofoidii and T. kofoidii are similar in shape, size, numbers and arrangement of epithecal and hypothecal plates. Cells of T. kofoidii were 27.5-32.5 $\mu \mathrm{m}$ long, 22.0-26.0 $\mu \mathrm{m}$ wide (Hoppenrath, 2000b); 27.0-34.0 $\mu \mathrm{m}$ long, 21-27 $\mu \mathrm{m}$ deep (Selina et al., 2019). Cells of $T$. pseudokofoidii were 23-37 $\mu \mathrm{m}$ long, 19-32 $\mu \mathrm{m}$ deep (Selina et al., 2019), 25-32 $\mu \mathrm{m}$ long and 24.5-35 $\mu \mathrm{m}$ deep (present study). T. pseudokofoidii could be distinguished from T. kofoidii by the 
ornamentation of thecal pores on the lateral hypothecal plates ( $2^{\prime \prime \prime}$ and $\left.4^{\prime \prime \prime}\right)$. In T. kofoidii, pores were scattered over the entire surface of the lateral plates. Whereas, pores were mainly concentrated along the margins of these plates and were devoided in the central area of plates in $T$. pseudokofoidii. Selina et al. (2019) showed that the pores on the lateral hypothecal plates (2"'"' and $\left.4^{\prime \prime \prime \prime}\right)$ of $T$. pseudokofoidii had fewer than $(37 \pm 4.2)$ those of $T$. kofoidii $(48 \pm 11)$. In contrast, $T$. pseudokofoidii in present study seem to have more pores $(65 \pm 20, \mathrm{n}=3)$ than those of $T$. kofoidii as described in previous study (Selina et al., 2019).

Distribution: So far, this species has only been reported in Japan, Russia and Viet Nam. T. pseudokofoidii was first discovered in sublittoral sands in Peter the Great Bay (northwest Sea of Japan), in Vostok Bay (Russia), with water temperature ranging from $-1.5^{\circ} \mathrm{C}$ (in February) to $20^{\circ} \mathrm{C}$ (in September) and salinities from 30-34 psu and 30-32 psu, respectively (Selina et al., 2019). This is the first reporting of T. pseudokofoidii species in Viet Nam and genus Thecadinium is a new addition to the dinoflagellate flora of Viet Nam, where the local waters are warmer than in either the sea of Japan or Russia. At the collection site, seawater temperature value ranged between $25^{\circ} \mathrm{C}$ and $29^{\circ} \mathrm{C}$ and the value of salinity had narrow range (32.5-33 psu). This species was rare during this sampling period.

\section{Class: Dinophyceae West \& Fritch 1927; \\ Order: Gymnodiniales Lemmermann 1910; Family: Gymnodiniaceae Lankaster 1885; Genus: Amphidinium Claparède \& Lachmann 1859}

Amphidinium herdmanii Kofoid and Swezy

(Figs 14-16) Synonym: Amphidinium operculatum Herdman

(Selina, 2016: fig. 3g; Hoppenrath et al., 2014: figs 14I-K; Al-Yamani and Saburova, 2010: Pl. 22a-f; Jørgensen et al., 2004: fig. 1C; Murray and Patterson, 2002b: figs 22-25, 79; Larsen and Patterson, 1990: figs 43a-b, 44e; Larsen, 1985: figs 20-25, 91)

Taxonomic remarks: Cell is quadrangular-broadly oblong, without thick theca, $26.5 \mu \mathrm{m}$ long and $23.5 \mu \mathrm{m}$ wide. Measurements in present study resemble those of previous descriptions for $A$. herdmanii at 26-33 $\mu \mathrm{m}$ long and 18-23 $\mu \mathrm{m}$ wide (Larsen, 1985), 27-32 $\mu \mathrm{m}$ long and 14-21 $\mu \mathrm{m}$ wide (Larsen and Patterson, 1990), 20-31 $\mu \mathrm{m}$ long and 15-25 $\mu \mathrm{m}$ wide (Murray and Patterson, 2002b) and 28-31 $\mu \mathrm{m}$ long and 22-24 $\mu \mathrm{m}$ wide (Al-Yamani and Saburova, 2010).

In ventral view, the epicone is short with a bent triangular shape, with $9 \mu \mathrm{m}$ long and slightly right deflection, protruding from the ventral side of the hypocone apex and extending dorsally (Fig. 14). From the dorsal side, the epicone is symmetrical, rising over the hypocone (Fig. 15). The narrow cingulum is short and V-shaped. The sulcus is narrow, beginning near the cell's center, then slightly widened at its posterior. The hypocone is quadrangular-broadly, notched at the antapex, and slightly asymmetrial, the left side being longer than the right side. The ratio of the epicone relative to total cell length is approximately one-third. The nucleus is crescent-shaped and positioned mainly in the posterior of the hypocone (Fig. 16). Living cells of Amphidinium herdmanii have gold-brown chloroplasts, cell swam freely. Chloroplasts appear single, with numerous lobes radiating from the center.

Distribution: This species is common world-wide, in temperate to tropical waters. This species was found in the UK (Lebour, 1925). Later, it has been recorded in Danish Wadden Sea (Jørgensen et al., 2004), Japan, Russia (Selina, 2016) and from tropical marine sediments in Australia (Murray and Patterson, 2002b) and Kuwait (Al-Yamani and Saburova, 2010). Amphidinium herdmanii is now recorded for the first time in Viet Nam. As observed in this study, this species does not appear to be common. 

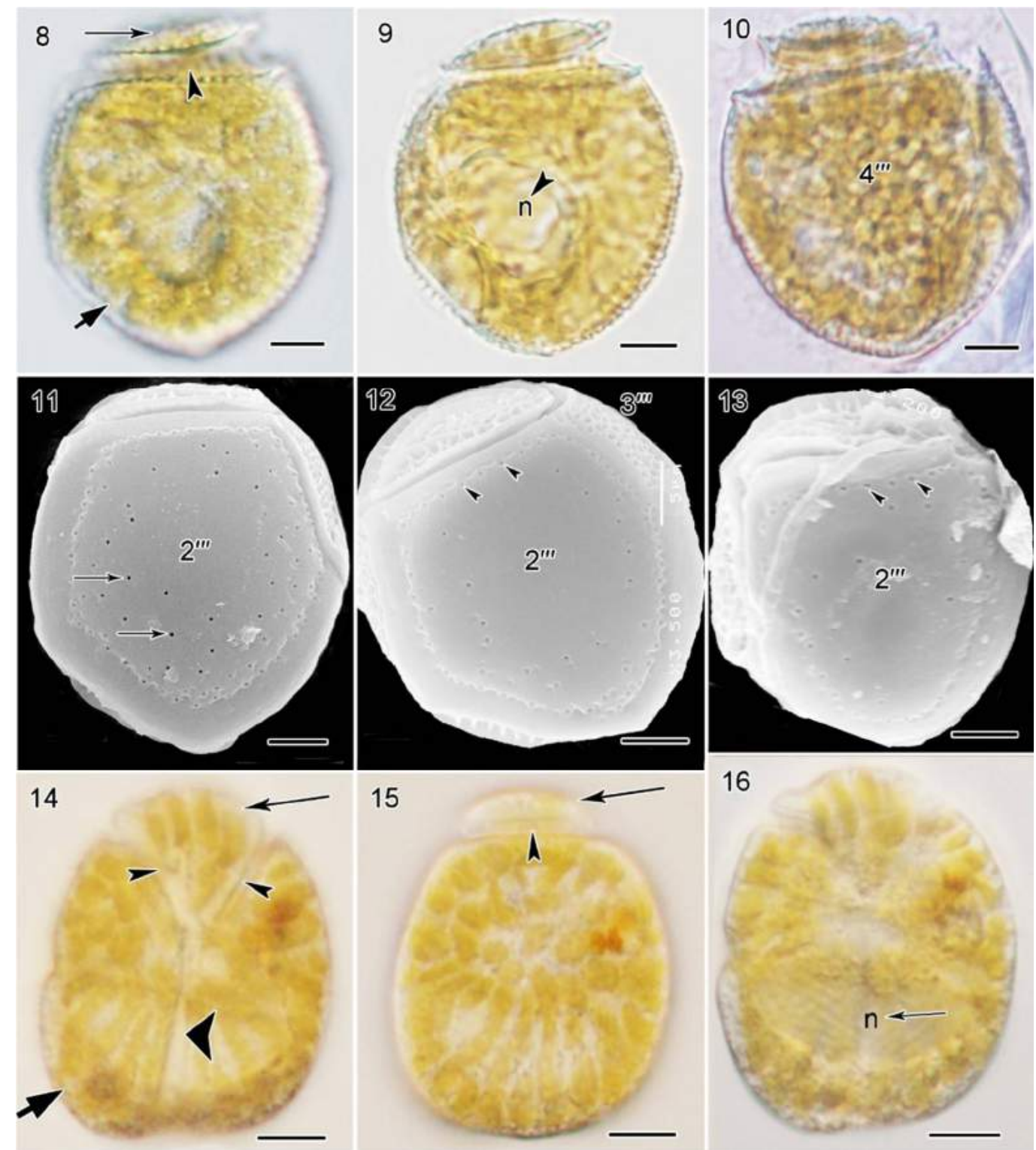

16

Figs 8-16. LM and SEM of Thecadinium pseudokofoidii (figs 8-13) and Amphidinium herdmanii (figs 1416: the same cell). Fig. 8. Left lateral view showing a small epitheca (long arrow), large hypotheca (arrow) and cingulum (arrowheads). Fig. 9. Left lateral view with nucleus (marked n) located in hypotheca (arrowhead). Fig. 10. Right lateral view showing the large postcingular plate (4"'). Figs 11-13. Left lateral view showing the thecal pores (arrows) and marginal pores (arrowheads) on smooth large postcingular plate $\left(2^{\prime \prime \prime}\right)$. Fig. 14. Ventral view showing a small epicone (long arrow) over a large hypocone (arrow) with elongated gold-brown chloroplasts; the V-shaped cingulum (arrowheads) and the sulcus (wide arrowhead). Fig. 15. Dorsal view showing an epicone (arrow) and cingulum groove (arrowhead). Fig. 16. Dorsal view showing nucleus (marked n) located in posterior part of hypocone (arrow). Scale bars: $5 \mu \mathrm{m}$. 
Class: Dinophyceae West \& Fritch 1927; Order: Gonyaulacales F.J.R. Taylor 1980; Family: Goniodomataceae Lindem 1928; Genus: Fukuyoa Gómez, Qiu, Lopes \& Lin 2015

Fukuyoa ruetzleri (Faust, Litaker, Vandersea, Kibler, Holland \& Tester) Gómez, Qiu, Lopes \& Lin

(Figs 17-28) Basionym: Gambierdiscus ruetzleri Faust, Litaker, Vandersea, Kibler, Holland \& Tester (Litaker et al., 2009: figs 43-59; Gómez et al., 2015; Leung et al. 2018: figs 5 A-J)

Taxonomic remarks: Cells have brown-yellow chloroplasts. Cells of $F$. ruetzleri are globular to obovoid shaped in apical or antapical view, varying from 54-57 $\mu \mathrm{m}$ long, 39-41 $\mu \mathrm{m}$ wide and $45-48 \mu \mathrm{m}$ deep. Along the vertical axis, the apex is deflected dorsally and the antapex is deflected ventrally (Figs 20-21). The epitheca is slightly shorter than the hypotheca. The thecal surface is thick, smooth and covered with numerous round pores of about $0.32-0.38 \mu \mathrm{m}$ in diameter, the thecal pores are evenly distributed (Fig. 28).
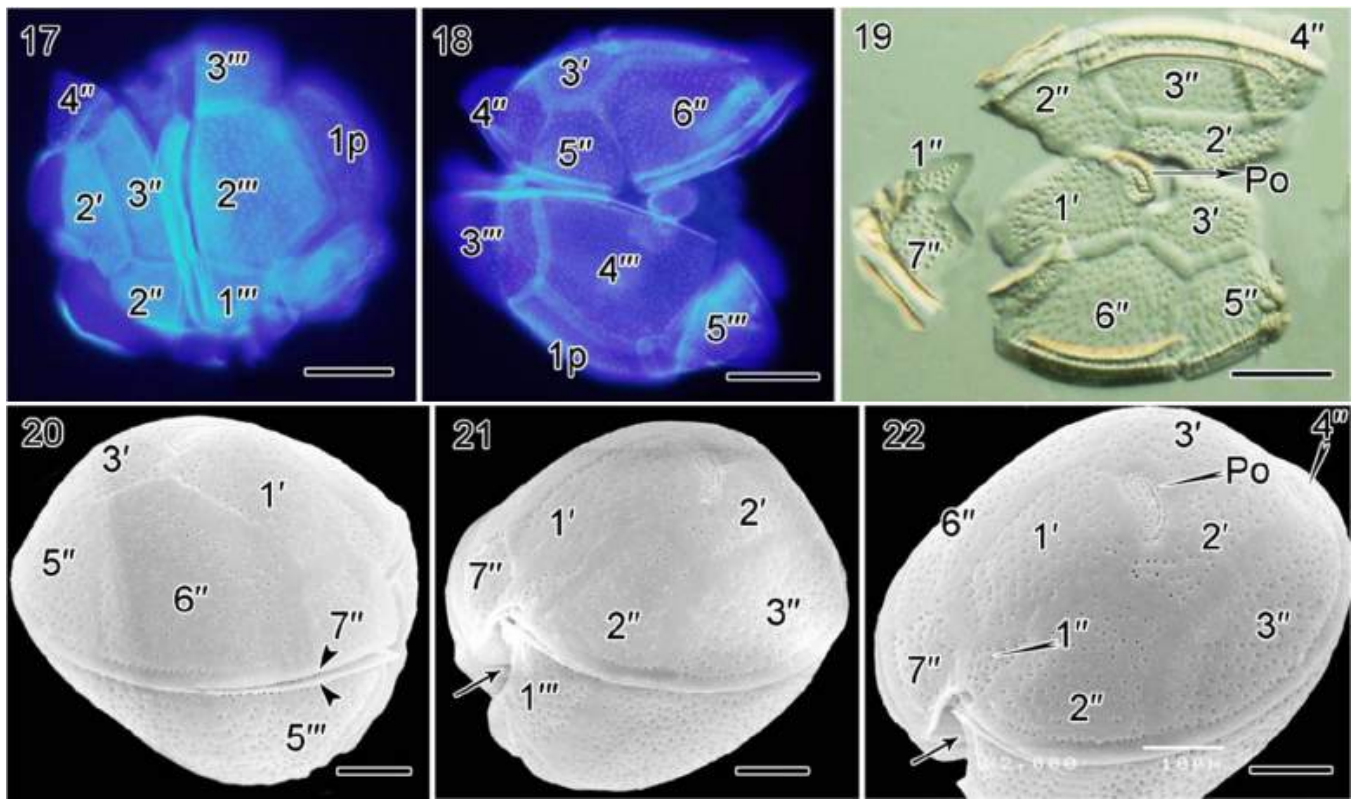

Figs 17-22. LM and SEM micrographs of Fukuyoa ruetzleri. Fig. 17. Right lateral view of the left of the cell.

Fig. 18. Left lateral view of the right of the cell showing epithecal and hypothecal plates. Fig. 19. Apical view showing all epithecal plates and Po (arrow). Fig. 20. Left lateral view of the right of the epitheca showing epithecal plates and cingulum (arrowheads). Figs 21-22. Right lateral view of the left of the epitheca showing epithecal plates, apical pore plate (Po) and sulcus (arrows). Scale bars: $10 \mu \mathrm{m}$.

Thecal plate arrangement is Po, 3', 7", 5"', $1 \mathrm{p}$ and 2'"' (The cingulum (c) and several sulcus (s) plates were not visible in the specimens of our study). The epitheca consists of eleven plates: Po, 3' and 7" (Figs 17-22). The apical pore plate is elongated and centrally positioned in the epitheca, 9-11 $\mu \mathrm{m}$ long, its largest width 3.5-4.0 $\mu \mathrm{m}$, with a fish-hook-shaped surrounded by 3839 round pores (Fig. 28). The apical plates contain three plates $\left(1^{\prime}, 2^{\prime}\right.$ and $\left.3^{\prime}\right)$. Plate $1^{\prime}$ is the largest, 
plate $2^{\prime}$ is long, narrow and five-sided, plate $3^{\prime}$ is pentagonal and medium in size. The precingular plates comprise seven plates (1", 2", 3", 4", 5", 6" and 7"). Plate 1" is pointed four-sided and the smallest in the series of precingular plates, followed by the trapezium-shaped 7" plate. Plates $3^{\prime \prime}$ and $6^{\prime \prime}$ are the largest of the epitheca. Plates $2^{\prime \prime}$ and $3^{\prime \prime}$ are quandrangular, whereas plates $4 ", 5^{\prime \prime}$ and $6 "$ are pentagonal (Figs 20-22). The cingulum is narrow and descended by twice its own width. The sulcus is deeply excavated (Figs 20-21).

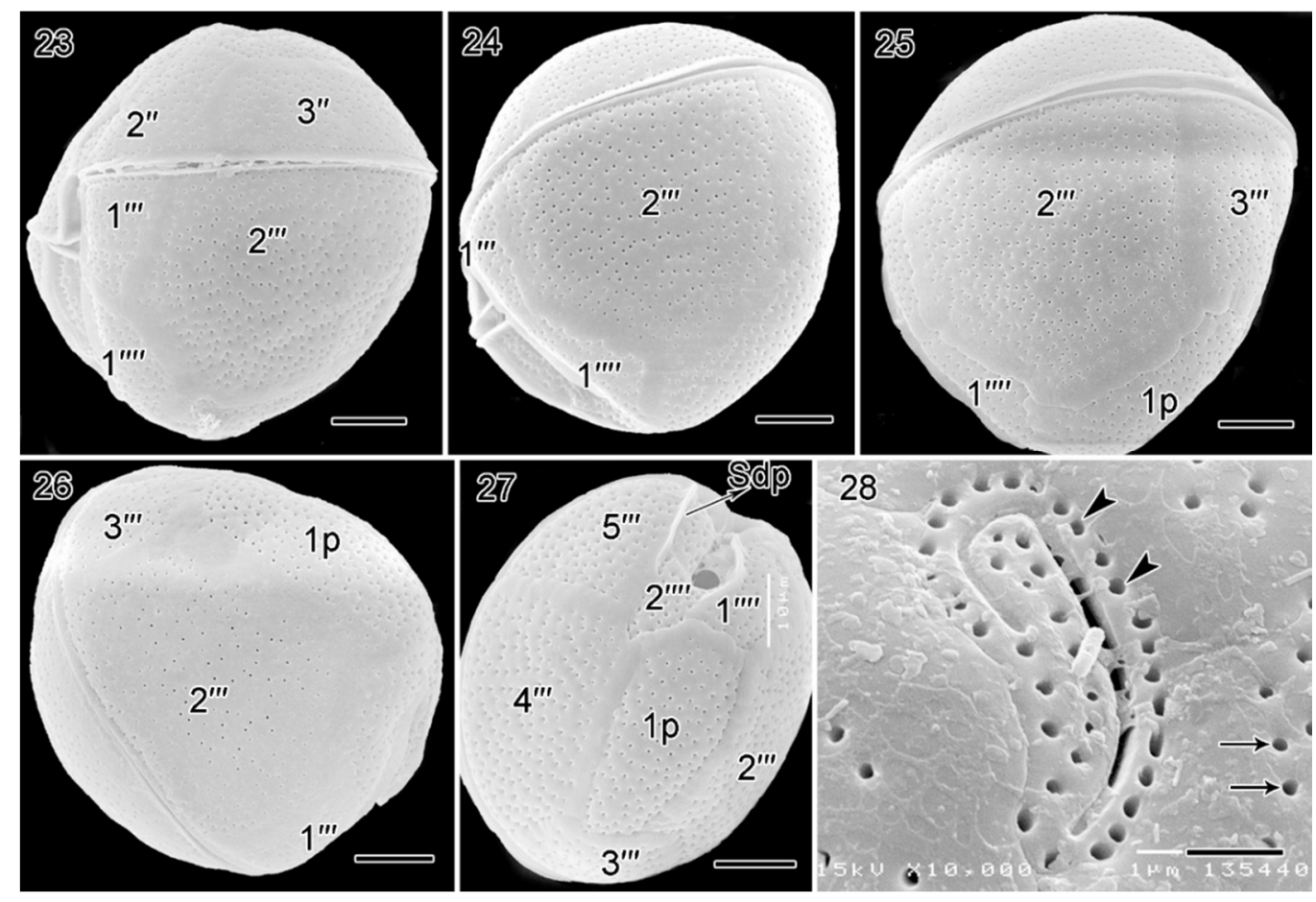

Figs 23-28. SEM micrographs of Fukuyoa ruetzleri. Figs 23-25. Right lateral view of the left of the hypotheca showing three postcingular (1"', $2^{\prime \prime \prime}$ and $\left.3^{\prime \prime \prime}\right)$, one antapical $\left(1^{\prime \prime \prime \prime}\right)$ and posterior intercalary (1p) plates. Fig. 26. Right lateral view of the left of the hypotheca showing three postcingular and posterior intercalary plates. Fig. 27. Antapical view showing hypothecal plates. Fig. 28. Detailed thecal surface showing numerous round pores (arrows) and apical pore plate ( $\mathrm{Po}$ ) with a fish-hook-shaped surrounded by many round pores (arrowheads). Scale bars: $10 \mu \mathrm{m}$, except Fig. 28: $2 \mu \mathrm{m}$.

The hypotheca is made up of eight plates: five postcingular plate (1"', $2^{\prime \prime \prime}, 3^{\prime \prime \prime}, 4^{\prime \prime \prime}$ and $\left.5^{\prime \prime \prime}\right)$, one posterior intercalary plate (1p) and two antapical plate (1"'"', $\left.2^{\prime \prime \prime \prime}\right)$ (Figs 23-27). Plates $1^{\prime \prime \prime}$ and $5^{\prime \prime \prime}$ are triangular and the smallest in the series of postcingular plates. Plate $3^{\prime \prime \prime}$ is quandragular and medium in size, plates $2^{\prime \prime \prime}$ and $4^{\prime \prime \prime}$ are quandragular and the largest (Figs 23, 27). The posterior intercalary plate (1p) is long and narrow, $27 \mu \mathrm{m}$ long, its largest width $15.8 \mu \mathrm{m}$ and positioned between plates $2^{\prime \prime \prime}$ and $44^{\prime \prime \prime}$ (Fig. 27). The antapical plate $1^{\prime \prime \prime \prime}$ is small, four-sided, and situated on the left side of the sulcus. The antapical plate $2^{\prime \prime \prime \prime}$ is forked, pointed and six-sided, it ocuppies the base of the sulcal hollow (Fig. 27).

At present, three Fukuyoa species viz., F. yasumotoi, F. ruetzleri and $F$. paulensis have been identified and described (Homles, 1998; Litaker et al., 2009; Gómez et al., 2015; Leung et al., 2018). The morphology of $F$. ruetzleri is highly similar to those of $F$. yasumotoi and F. paulensis 
(Figs 29, 32, 35). However, three species could be distinguished by a number of morphological characteristics. According to Litaker et al. (2009), the cell demensions of F. ruetzleri are $52 \pm 5$ $\mu \mathrm{m}$ long (range 45-59), $37 \pm 3 \mu \mathrm{m}$ wide (31-42), and $45 \pm 3 \mu \mathrm{m}$ deep (42-45) and for $F$. yasumotoi is $62 \pm 4 \mu \mathrm{m}$ long (range 54-68), $52 \pm 5 \mu \mathrm{m}$ wide (43-60) and $57 \pm 5 \mu \mathrm{m}$ deep (49-67). Gómez et al. (2015) reported that the demensions of $F$. paulensis are $56 \pm 3 \mu \mathrm{m}$ long (range $51-$ $62), 45 \pm 2 \mu \mathrm{m}$ wide (41-48) and $50 \pm 3 \mu \mathrm{m}$ deep (45-56). Of the three species, cell demensions of $F$. yasumotoi are the biggest, followed by $F$. paulensis and $F$. ruetzleri smallest. Besides, plate $1^{\prime}$ is nearly rectangular in $F$. yasumotoi (Fig. 30) or broadly pentagonal in $F$. paulensis (Fig. 33) whereas plate $1^{\prime}$ is narrow pentagonal in $F$. ruetzleri (Fig. 36). Plate $2^{\prime \prime \prime \prime}$ of $F$. yasumotoi and $F$. paulensis is more larger and broader than those in $F$. ruetzleri. The posterior intercalary plate $1 \mathrm{p}$ is elongated, narrow and pentagonal in $F$. ruetzleri and broader than in F. paulensis and $F$. yasumotoi (Figs 31, 34, 37). From the previous descriptions and above comparisons, the specimens of our present study were described and identified as F. ruetzleri.
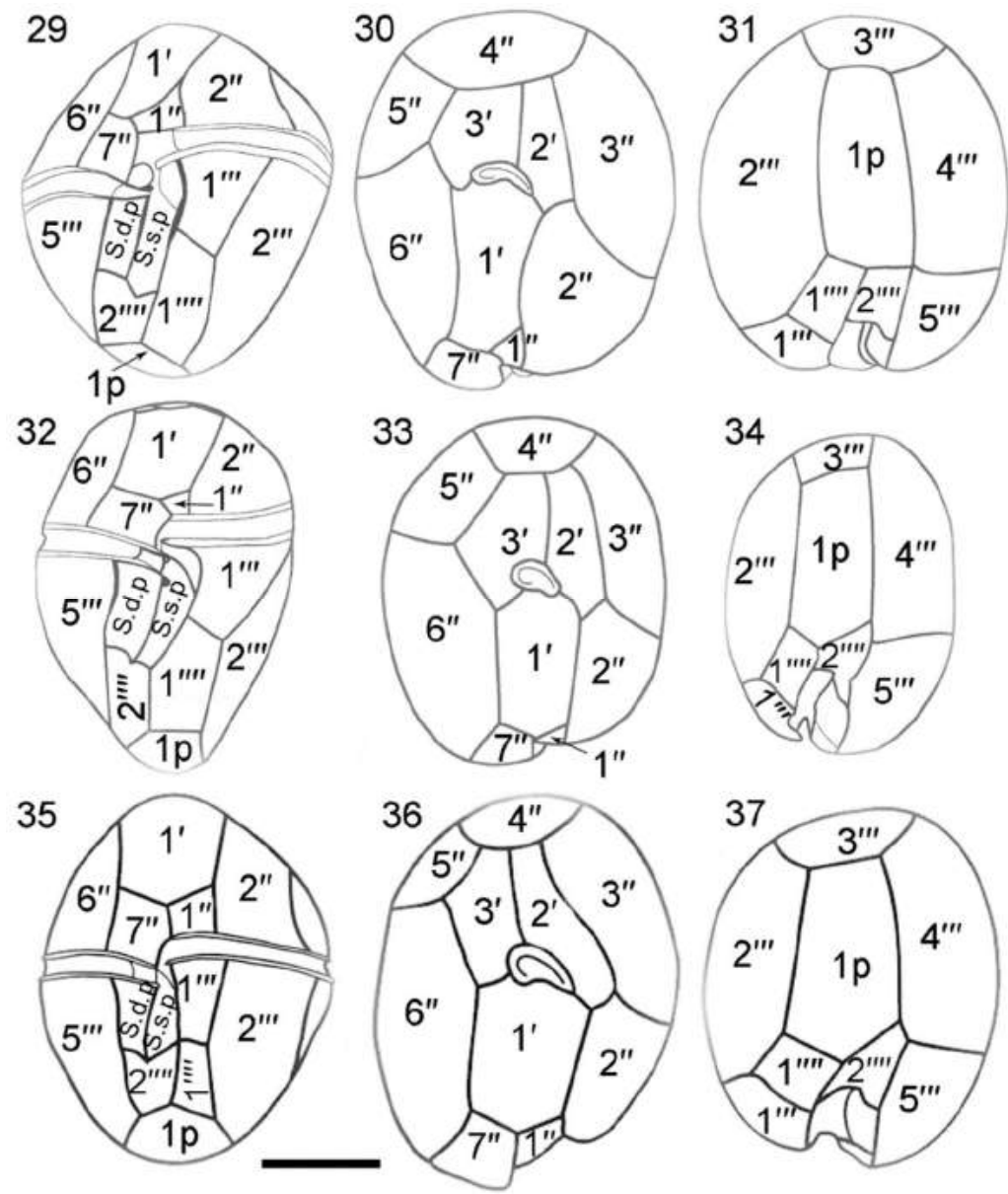

Figs 29-37. Thecal plate tabulation of Fukuyoa species. Figs 29-31: F. yasumotoi. Figs 32-34: F ruetzleri (Redrawn from Litaker et al., 2009). Figs 35-37: F. paulensis (Redrawn from Gómez et al., 2015). Figs 29, 32 \& 35: Ventral. Figs 30, 33 \& 36: Epitheca. Figs 31, 34 \& 37: Hypotheca. Scale bar: 20 m. 
Distribution: Previously, F. ruetzleri has been reported in Caribbean Sea, Belize, Central America to North Carolina, it was associated with macroalgae (Litaker et al., 2009). Recently, this species has been found to be associated with surface of rocks and dead corals from the coast of Hong Kong, it can produce a compound putatively assigned as MTX-3 (Leung et al., 2018). This is the first description of $F$. ruetzleri in Viet Nam, with water temperature ranging from $25^{\circ} \mathrm{C}$ to $29^{\circ} \mathrm{C}$ and salinities of 32.5-33 psu during collection time. This species does not appear to be common in our study.

\section{Acknowledgements}

This work was supported by the YEOSU Project (Korea), the National Foundation for Science and Technology Development is acknowledged for funding the first author (Project number 106.06-2017.305). We thank Dr. Shauna Murray (University of NSW, Sydney, Australia) for improving the manuscript with useful comments. This paper is a contribution to celebrate the 100th anniversary of the Institute of Oceanography, Vietnam Academy of Science and Technology.

\section{References}

Al-Yamani, F.Y. and Saburova, M.A. 2010. Illustrated Guide on the Flagellates of Kuwait's Intertidal Soft Sediments. Kuwait Institute for Scientific Research, Lucky Press, pp. 1-197.

Faust, M.A. 1995. Benthic, toxic dinoflagellates: An overview. In: Lassus, P., Arzul, G., Erard, E., Gentien, P. and Marcaillou, C. (Eds.). Harmful Marine Algal Blooms. Technique at Documentation - Lavoisier, Intercept Ltd., pp. 847-854.

Gómez, F., Qiu, D., Lopes, R.M. and Lin, S. 2015. Fukuyoa paulensis gen. et sp. nov., a new genus for the globular species of the dinoflagellate Gambierdiscus (Dinophyceae). PLoS ONE 10(4): e0119676. doi:10.1371/journal.pone.0119676

Ho, V.T. and H'Yon, N.B. 2019. First report of Gambierdiscus caribaeus and G. carpenteri (Dinophyceae) from Nha Trang Bay, South Central Vietnam. Journal of the Marine Biological Association of India 60(2): $5-11$.

Ho, V.T. and Nguyen, N.L. 2014. Morphology and distribution of the three epiphytic dinoflagellate species Coolia monotis, C. tropicalis, and C. canariensis (Ostreopsidaceae, Gonyaulacales, Dinophyceae) from Vietnamese coastal waters. Ocean Science Journal 49(3): 211-221.

Ho, V.T., Nguyen, N.L. and Doan, N.H. 2010. Benthic dinoflagellates in Vietnamese waters. Publishing House for Science and Technology. Ha Noi. pp. 1-138.

Holmes, M.J. 1998. Gambierdiscus yasumotoi sp. nov. (Dinophyceae), a toxic benthic dinoflagellate from southeastern Asia. Journal of Phycology 34: 661-668.

Hoppenrath, M., Murray, S.A., Chomérat, N. and Horiguchi, T. 2014. Marine benthic dinoflagellates Unveiling their worldwide biodiversity. Kleine Senckenberg-Reihe 54, Druckerei Lokay e.K., Reinheim, Germany. pp. 1-276

Hoppenrath, M., Selina, M., Yamaguchi, A. and Leander, B. 2012. Morphology and molecular phylogeny of Amphidiniopsis rotundata sp. nov. (Peridiniales, Dinophyceae), a benthic marine dinoflagellate. Phycologia 51(2): 157-167.

Hoppenrath, M., Koeman, R.P.T. and Leander, B.S. 2009. Morphology and taxonomy of a new marine sanddwelling Amphidiniopsis species (Dinophyceae, Peridiniales), A. aculeata sp. nov., from Cap Feret, France. Marine Biodiversity 39: 1-7.

Hoppenrath, M. 2000a. Morphology and taxonomy of six marine sand-dwelling Amphidiniopsis species (Dinophyceae, Peridiniales), four of them new, from the German Bight. North Sea. Phycologia 39(6): 482-497. 
Hoppenrath, M. 2000b. Morphology and taxonomy of marine sand-dwelling genus Thecadinium (Dinophyceae), with the description of two new species from the North German Wadden Sea. Phycologia 39(2): 96-108.

Jørgensen, M.F., Murray, S. and Daugbjerg, N. 2004. Amphidinium revisited. I. Redefinition of Amphidinium (Dinophyceae) based on cladistic and molecular phylogenetic analyses. Journal of Phycology 40: 351365.

Larsen, J. 1985. Algal studies of the Danish Wadden Sea. II. A taxonomic study of psammobious dinoflagellates. Opera Botanica 79: 14-37.

Larsen, J. and Patterson, D.J. 1990. Some flagellates (Protista) from tropical marine sediments. Journal of Natural History 24: 801-937.

Lebour, M.V. 1925. The Dinoflagellates of Northern Sea. Marine Biological Association of the United Kingdom, Plymouth. pp. 1-235.

Litaker, R.W., Vandersea, M.W., Faust, M.A., Kibler, S.R., Chinain, M., Holmes, M.J., Holland, W.C. and Tester, P.A. 2009. Taxonomy of Gambierdiscus including four new species, Gambierdiscus caribaeus, Gambierdiscus carolinianus, Gambierdiscus carpenteri and Gambierdiscus ruetzleri (Gonyaulacales, Dinophyceae). Phycologia 48: 344-390.

Leung, P.T.Y., Yan M., Lam, V.T.T., Yiu, S.K.F., Chen, C.Y., Murray, J.S., Harwood, D.T., Rhodes, L.L., Lam, P.K.S. and Wai, T.C. 2018. Phylogeny, morphology and toxicity of benthic dinoflagellates of the genus Fukuyoa (Goniodomataceae, Dinophyceae) from a subtropical reef ecosystem in the South China Sea. Harmful Algae 74: 78-97

Murray S.A. 2003. Diversity and phylogenetics of sand-dwelling dinoflagellates from southern Australia. PhD Thesis. University of Sydney, Sydney, Australia. 202 pp.

Murray, S. and Patterson, D. 2002a. Amphidiniopsis korewalensis sp. nov., a new heterotrophic benthic dinoflagellate. Phycologia 41: 382-388.

Murray, S. and Patterson, D. 2002b. The benthic dinoflagellate genus Amphidinium in south-eastern Australian waters, including three new species. European Journal of Phycology 37: 279-298.

Nguyen, N.L. and Larsen, J. 2004. Gonyaulacales. In: Larsen, J. and Nguyen, N.L. (Eds.). Guide to the Identification of Potentially Toxic Microalgae in Vietnamese Waters. Opera Botanica 140, Copenhagen, pp.73-116.

Reñé, A., Satta, C.T., López-García, P. and Hoppenrath, M. 2020. Re-evaluation of Amphidiniopsis (Dinophyceae) morphogroups based on phylogenetic relationships, and description of three new sanddwelling species from the NW Mediterranean. Journal of Phycology 56(1): 68-84.

Selina, M.S., Efimova, K.V. and Hoppenrath, M. 2019. Redefinition of the genus Thecadinium (Dinophyceae) using morphological and molecular data, and description of Thecadinium pseudokofoidii sp. nov.. Phycologia 58(1): 36-50.

Selina, M.S. and Morozova, T.V. 2017. Morphology and taxonomy of three new marine sand-dwelling Amphidiniopsis species (Peridiniales, Dinophyceae) from the Sea of Japan, Russia. Phycologia 56(1): $1-13$.

Selina, M.S. 2016. Seasonal and long-term dynamics of sand-dwelling dinoflagellates (Dinoflagellata) in Peter the Great Bay, Sea of Japan. Russian Journal of Marine Biology 42(6): 458-470

Selina, M. and Hoppenrath, M. 2013. Morphology and taxonomy of seven marine sand-dwelling Amphidiniopsis species (Peridinales, Dinophyceae), including two new species, A. konovalovae sp. nov. and A. striata sp. nov., from the Sea of Japan, Russia. Marine Biodiversity 43: 87-104.

Tester, P.A., Kibler, S.R., Holland, W.C., Usup, G., Vandersea, M.W., Leaw, C.P., Lim, P.T., Larsen, J., Mohammad-Noor, N., Faust, M.A. and Litaker, R.W. 2014. Sampling harmful benthic dinoflagellates: Comparison of artificial and natural substrate methods. Harmful Algae 39: 8-25.

Toriumi, S., Yoshimatsu, S. and Dodge, J.D. 2002. Amphidiniopsis uroensis sp. nov. and Amphidiniopsis pectinaria sp. nov. (Dinophyceae): Two new benthic dinoflagellates from Japan. Phycological Research 50: $115-124$. 
Yoshimatsu, S., Toriumi, S. and Dodge, J.D. 2000a. Light and scanning microscopy of two benthic species of Amphidiniopsis (Dinophyceae), Amphidiniopsis hexagona sp. nov. and Amphidiniopsis swedmarkii from Japan. Phycological Research 48: 107-113.

Yoshimatsu, S., Toriumi, S. and Dodge, J.D. 2000b. Morphology and taxonomy of five marine sand-dwelling Thecadinium species (Dinophyceae) from Japan, including four new species: Thecadinium arenarium sp. nov., Thecadinium ovatum sp. nov., Thecadinium striatum sp. nov., and Thecadinium yashimaense sp. nov.. Phycological Research 52: 211-223.

(Manuscript received on 8 July 2021; revsied on 8 December 2021) 